\title{
An analysis of the main driving factors of renewable energy consumption in the European Union
}

\author{
José Antonio Camacho Ballesta ${ }^{1,2}\left(\right.$ C) $\cdot$ Lucas da Silva Almeida ${ }^{2,3}\left(\right.$ Mercedes Rodríguez $^{1,2}$ (])
}

Received: 21 May 2021 / Accepted: 13 January 2022 / Published online: 19 January 2022

(c) The Author(s) 2022

\begin{abstract}
Climate change is a major global concern closely related to the strategies aimed at reducing energy consumption and increasing energy efficiency. Over the last decades, the interest in the development of renewable energy (RE) has grown exponentially. In the case of the European Union (EU), the Renewable Energy Directive sets rules to achieve a 32\% of total energy consumption to be covered through RE by 2030. In order to achieve this goal, it is important to know what are the main driving factors of RE consumption (REC). This study aims to analyze the impact of economic and social factors on the share of REC in total energy consumption in the EU over the period 2001-2015. For doing so, we estimate a Panel Corrected Standard Error (PCSE) model. The results obtained show that economic factors have a negative effect on REC. In contrast, social factors like education exert a positive effect. This suggests that it is necessary to adopt a holistic approach that includes not only economic but also social aspects in order to foster REC.
\end{abstract}

Keywords Renewable energy $\cdot$ Economic factors $\cdot$ Social factors $\cdot$ Energy transition $\cdot$ Data panel $\cdot$ European Union

JEL Classification O52 · Q20 · Q42

\section{Introduction}

Climate change is a major global concern. The strategy to reverse the current situation is closely related to the way in which energy is generated and consumed. In this regard, renewable energy (RE) is a key element that contributes, not only to the conservation of the environment, but also to economic and social development (Saint Akadiri et al. 2019).

Concerning the production of RE, the data from the International Energy Agency (IEA) reveal that the share of primary energy from renewable sources in the world has hardly

Responsible Editor: Roula Inglesi-Lotz

Lucas da Silva Almeida

lucasalmeida@famam.com.br; lucasalmeida@correo.ugr.es

1 Department of International and Spanish Economics, Faculty of Economics and Business, University of Granada, 18071 Granada, Spain

2 Institute of Regional Development, University of Granada, 18071 Granada, Spain

3 University Center Maria Milza, Governador Mangabeira 44350, Brazil changed over the last decades. Thus, in $1971 \mathrm{RE}$ accounted for $13.1 \%$ of primary energy. In 2018 the share was almost identical: $13.8 \%$ (IEA 2020a). This slow pace of change is explained by a wide range of problems from the inefficient way in which some people and firms use energy to the lack of information and/or knowledge on the importance of clean energy, the existence of market failures or the accessibility to raw materials (Painuly 2001; Owen 2006; Verbruggen et al. 2010; Sen and Ganguly 2017).

Regarding the consumption of RE, according to the global renewable community of actors REN21, in 2019 renewable energy consumption (REC) accounted for $19.9 \%$ of world total final energy consumption (TFEC) (REN21 2021). REN21 differentiates between modern renewable energies and traditional biomass. Thus, as of 2019 , modern renewable energies accounted for $11.2 \%$ of TFEC, 2.5 percentage points more than a decade earlier. Within modern renewable energies, the most important one was renewable electricity, which represented $6 \%$ of TFEC, followed by renewable heat (4.2\%) and transport biofuels (1\%) (REN21 2021).

The European Union (EU) is aware of the importance of REC as a facilitating tool for meeting the sustainable development goals (SDGs) proposed by the United Nations (UN), 
and, in particular, for the achievement of an affordable and non-polluting energy system. Beyond contributing to the reduction of greenhouse gas emissions and to the diversification of energy supply, REC is also a tool to reduce the dependence on non-EU fossil fuels markets, considered to be volatile and unreliable (European Parliament 2019). For 2030 the initial target of $27 \%$ of total energy consumption to be covered through RE has been rised to a percentage of at least 32\%, as reported in Directive (EU) 2018/2001 (European Union 2018). Meeting this objective is a major challenge. According to the data published by Eurostat (2021), in 2019 REC represented $19.7 \%$ of the energy consumed in the EU27. There are, however, important differences across countries. Thus, for one part we find countries that more than double the EU27 average, like Sweden $(56.4 \%)$ or Finland $(43.1 \%)$. For the other part, there are countries with a very low share of REC, like Luxembourg (7\%), the Netherlands $(8.8 \%)$ or Malta (8.5\%).

Direct policy support, in the form of economic, administrative, financial and regulatory support measures, is essential for the deployment of RE. In 2015, the last year analyzed in our study, more than 1300 support measures for the development of RE were in place in the EU countries. Feed-in-tariff and feed-in-premiums were the main supporting schemes in the electricity sector, and they were applied in $24 \mathrm{EU}$ countries (Banja et al. 2018). In recent years the interest is shifting away towards auctions, as they lead to lower prices and higher realization rates (REN21 2021).

In their seminal study on the relationship between gross energy consumption and gross domestic product (GDP), Kraft and Kraft (1978) found a bidirectional causality between these two variables. Following this line of analysis, different studies have examined the link between REC and other variables, not only, related to economic growth like GDP but also related to trade, foreign direct investment (FDI) or $\mathrm{CO}_{2}$ emissions. The results of these studies are various and varied. Although a growing strand of the literature deals with REC, very few papers have analyzed the driving factors of the share of REC in total energy consumption (Ito 2017; Attiaoui et al. 2017; Mele 2019; Toumi and Toumi 2019; Ergun et al. 2019; Anton and Afloarei Nucu 2020; Khan et al. 2020; Khribich et al. 2021; Marra and Colantonio 2021; Lei et al. 2021). This paper examines the main driving factors of the share of REC in the EU over the period 2001-2015 by estimating a Panel Corrected Standard Errors (PCSE) model. It contributes to the extant literature in two main ways. First, we examine the impact of both economic and social factors. A large body of the literature on the driving forces of REC includes economic variables. However, there is a lack of evidence on the impact of social factors, especially in high-income countries. Among the factors that affect RE uptake we can highlight political conditions and governance, as they directly affect public support of RE. For this reason, within our group of social factors, in addition to indices on life expectancy and education, we include an index of governance. This index is constructed by combining six different indicators. Second, we carry out our analysis at the world level and at the EU level in order to identify the existence of differential features in the EU. Many of the drivers of RE deployment depend on national contexts. In particular demographics and socio-economic characteristics shape the pace and nature of REC. Thus, we can expect the same factor to have a different effect depending on the region or country examined.

The article is organized as follows. The second section presents a brief literature review on those works dealing with REC. The third section describes the data and methodology employed. Next, we discuss the main results. Finally, we summarize the main findings and make some policy recommendations.

\section{The driving forces of renewable energy consumption: a review of the literature}

To know in depth the determinants of REC is key when designing efficient energy strategies. The literature dealing with the driving forces of REC employ four main variables to proxy REC, namely, the total renewable energy consumption (TREC) (Apergis and Payne 2010a; Apergis et al. 2010; Salim and Shafiei 2014; Salim et al. 2014; Lin and Moubarak 2014; Ben Aïssa et al. 2014; Ben Jebli 2016; Doytch and Narayan 2016; Saidi and Ben Mbarek 2016; Cherni and Jouini 2017; Chen 2018; Rasoulinezhad and Saboori 2018; Marinaş et al. 2018; Nguyen and Kakinaka 2019; Eren et al. 2019; Olanrewaju et al. 2019; Zhao et al. 2020; Sohail et al. 2021; Baye et al. 2021), the renewable energy consumption per capita (RECpc) (Sadorsky 2009a, b; Salim and Rafiq 2012; Apergis and Payne 2014; Omri et al. 2015; Ben Jebli et al. 2015; Ben Jebli and Ben Youssef 2017; Hashemizadeh et al. 2021), the renewable electric energy consumption (REEC) (Apergis and Payne 2010b, 2011, 2012; AlMulali et al. 2013; Sebri and Ben-Salha 2014; Amri 2017, 2019) and the share of renewable energy consumption in total energy consumption (REC\%) (Ito 2017; Attiaoui et al. 2017; Mele 2019; Toumi and Toumi 2019; Ergun et al. 2019; Anton and Afloarei Nucu 2020; Khan et al. 2020; Khribich et al. 2021; Marra and Colantonio 2021; Lei et al. 2021). Table 1 presents a summary of the main studies conducted to date.

Most of studies employ TREC and include GDP per capita as an explanatory factor that represents income and the level of development. Other common economic explanatory factors are FDI and trade openness (TO). Concerning FDI, Doytch and Narayan (2016) examine the impact of the sectoral distribution of FDI on industrial REC in 74 countries 
Table 1 Previous studies on the driving forces of REC

\begin{tabular}{|c|c|c|c|c|}
\hline Authors & Period & Countries & Methodology & $\begin{array}{l}\text { Proxy } \\
\text { for REC }\end{array}$ \\
\hline Al-Mulali et al. (2013) & 1980-2009 & 109 countries & FMOLS & REEC \\
\hline Amri (2017) & 1990-2012 & 72 countries & GMM; Dynamic panel estimator Blundell-Bond & REEC \\
\hline Amri (2019) & 1990-2012 & 72 countries & GMM & REEC \\
\hline Anton and Afloarei Nucu (2020) & $1990-2015$ & $28 \mathrm{EU}$ countries & Fixed effects panel model & $\mathrm{REC} \%$ \\
\hline Apergis and Payne (2010a) & 1992-2007 & 13 Eurasia countries & VECM; Granger-causality tests & REEC \\
\hline Apergis and Payne (2010b) & $1985-2005$ & 20 OECD countries & VECM; Granger-causality tests & TREC \\
\hline Apergis and Payne (2011) & 1990-2007 & 80 countries & Panel error correction models & REEC \\
\hline Apergis and Payne (2012) & 1990-2007 & 80 countries & VECM; causal dynamics & REEC \\
\hline Apergis and Payne (2014) & 1980-2010 & 7 Central American countries & Long-run cointegration vector using FMOLS & RECpc \\
\hline Apergis et al. (2010) & $1984-2007$ & 19 developed and developing countries & $\begin{array}{l}\text { Dynamic error correction model, Granger causal- } \\
\text { ity }\end{array}$ & TREC \\
\hline Apergis et al. (2018) & 1995-2011 & 42 Sub-Saharan Africa countries & Granger causality tests & $\mathrm{REC} \%$ \\
\hline Attiaoui et al. (2017) & 1990-2011 & 22 African countries & ARDL-PMG; Granger causality & $\mathrm{REC} \%$ \\
\hline Baye et al. (2021) & 1990-2015 & 32 Sub-Saharan Africa countries & ARDL & TREC \\
\hline Ben Aïssa et al. (2014) & 1980-2008 & 11 African countries & VECM & TREC \\
\hline Ben Jebli (2016) & 1990-2011 & Tunisia & ARDL & TREC \\
\hline Ben Jebli and Ben Youssef (2017) & 1980-2011 & Tunisia & VECM; Granger causality tests & RECpc \\
\hline Ben Jebli et al. (2015) & 1980-2010 & 24 sub-Saharan Africa countries & Granger causality tests & RECpc \\
\hline Chen (2018) & 1996-2013 & China & GMM & TREC \\
\hline Cherni and Jouini (2017) & 1990-2015 & Tunisia & ARDL and Granger causality tests & TREC \\
\hline Doytch and Narayan (2016) & 1985-2012 & 74 countries & GMM; Dynamic panel estimator Blundell-Bond & TREC \\
\hline Eren et al. (2019) & $1971-2015$ & India & $\begin{array}{l}\text { Quasi-GLS; Cointegration test; DOLS and } \\
\text { Granger causality }\end{array}$ & TREC \\
\hline Ergun et al. (2019) & 1990-2013 & 21 African countries & FE and RE GLS & $\mathrm{REC} \%$ \\
\hline Hashemizadeh et al. (2021) & 1990-2016 & 20 emerging countries & DKSE; FGLS; PCSE & RECpc \\
\hline Ito (2017) & $2002-2011$ & 42 developing countries & GMM; PMG & REC $\%$ \\
\hline Khan et al. (2020) & 1980-2018 & 192 countries & Panel quantile regression model & $\mathrm{REC} \%$ \\
\hline Khribich et al. (2021) & $1995-2015$ & 27 countries & Granger causality tests & $\mathrm{REC} \%$ \\
\hline Lei et al. (2021) & 1990-2019 & China & ARDL & $\mathrm{REC} \%$ \\
\hline Lin and Moubarak (2014) & 1977-2011 & China & ARDL & TREC \\
\hline Marinaş et al. (2018) & 1990-2014 & $10 \mathrm{EU}$ members from CEE & PMG estimator for the error correction models & TREC \\
\hline Marra and Colantonio (2021) & 1990-2015 & $12 \mathrm{EU}$ countries & PVAR model & REC $\%$ \\
\hline Mele (2019) & $1980-2017$ & Mexico & Multivariate Granger causality tests & $\mathrm{REC} \%$ \\
\hline Nguyen and Kakinaka (2019) & 1990-2013 & 107 countries & FMOLS and DOLS & TREC \\
\hline Olanrewaju et al. (2019) & 1990-2015 & 5 African countries & Pooled OLS, Panel FE and RE & TREC \\
\hline Omri et al. (2015) & 1990-2011 & 64 countries & Pooled OLS; Panel FE and RE; GMM & RECpc \\
\hline Rasoulinezhad and Saboori (2018) & $1992-2015$ & CIS region countries & FMOLS; DOLS & TREC \\
\hline Sadorsky (2009a) & 1980-2005 & G7 countries & Cointegration of panels; FMOLS; DOLS & RECpc \\
\hline Sadorsky (2009b) & 1994-2003 & 18 emerging countries & FMOLS; DOLS; OLS & RECpc \\
\hline Saidi and Ben Mbarek (2016) & $1990-2013$ & 9 developed countries & Granger causality; FMOLS; DOLS & TREC \\
\hline Salim and Rafiq (2012) & 1980-2006 & 6 emerging economies & $\begin{array}{l}\text { ARDL; FMOLS; DOLS; and Granger causality } \\
\text { tests }\end{array}$ & RECpc \\
\hline Salim and Shafiei (2014) & 1980-2011 & 29 OECD countries & Common Correlated Effects & TREC \\
\hline Salim et al. (2014) & 1980-2012 & 29 OECD countries & PMG; ARDL & TREC \\
\hline Sebri and Ben-Salha (2014) & 1971-2010 & 3 BRICS countries & ARDL; FMOLS, DOLS & REEC \\
\hline Sohail et al. (2021) & 1985-2019 & USA & ARDL; NARDL & TREC \\
\hline Toumi and Toumi (2019) & 1990-2014 & Saudi Arabia & NARDL & $\mathrm{REC} \%$ \\
\hline Zhao et al. (2020) & 1980-2016 & China & OLS; FMOLS & TREC \\
\hline
\end{tabular}

$A R D L$ autoregressive distributed lag model, $D O L S$ dynamic ordinary lest squares, $D K S E$ Driscoll-Kraay standard errors, $F E$ fixed effects, $F G L S$ feasible generalized least squares, $F M O L S$ fully modified least square, $G L S$ generalized least squares, $G M M$ generalized method of moments, $N A R D L$ non-linear autoregressive distributed lag model, $O L S$ ordinary least squares, PCSE Panel Corrected Standard Errors, $P M G$ pooled mean group, $P V A R$ panel vector autoregressive, $R E$ random effects, $V E C M$ vector correction model 
over the period 1985-2012. They find that total FDI encourages industrial REC, but that there are differential impacts at the sectoral level. Thus, while financial service FDI fosters REC manufacturing FDI reduces REC. In their analysis of 21 African countries between 1990 and 2013, Ergun et al. (2019) also find a positive impact of FDI on REC\%. However, the study for 192 countries over the period 1980-2018 conducted by Khan et al. (2020) obtains heterogenous results for FDI. Thus, in their panel quantile regression non-significant results at low quantile become positive and significant at higher quantiles. They conclude that FDI reduces REC\% in lower countries and increases in higher ones. In contrast, Anton and Afloarei Nucu (2020) find a negative relationship between FDI and REC\% in the EU countries during the period 1990-2015, and Lei et al. (2021), in their analysis of China, do not find any link between FDI and REC\%. The findings on the relationship between TO and REC are either uniform. For one part, some studies obtain a positive relationship between trade and REC (Sebri and Ben-Salha 2014; Amri 2017, 2019; Rasoulinezhad and Saboori 2018), and, for the other part, other studies show the existence of a negative relationship between TO and REC. Thus, Amri (2017), in his analysis of 72 countries over the period 1990-2012, obtains a positive effect of trade on REEC in all groups of countries. Nonetheless, the shape of the impact differs between developed/industrialized countries and developing/ non-industrialized ones: while in developed/industrialized countries the relationship shows a U-shape, in the case of developing/non industrialized countries the relationship has an inverted U shape (Amri 2019; Naqvi et al. 2020). The analysis of 12 countries of the Commonwealth of Independent States (CIS) region between 1992 and 2015 carried out by Rasoulinezhad and Saboori (2018) finds the existence of a bidirectional relationship between TO and renewable energy use. In the case of the BRICS countries, the study for the period 1971-2010 conducted by Sebri and BenSalha (2014) shows the existence of a significant effect of TO on REEC. In their analysis of 20 emerging countries between 1990 and 2016, Hashemizadeh et al. (2021) find that TO decreases RECpc. In the same vein, the studies by Ergun et al. (2019) and Khan et al. (2020) obtain a negative impact of TO on REC\%. Finally, in their analysis of China, Zhao et al. (2020) find that TO raises non-renewable energy consumption.

Turning to social factors, we have to highlight that the incorporation of this type of factors is less common. We can cite the studies of Apergis et al.(2018), Baye et al. (2021), Ben Jebli (2016), Ergun et al. (2019), Khribich et al. (2021) and Marra and Colantonio (2021). In their examination of a panel of 42 sub-Saharan Africa countries over the period 1995-2011, Apergis et al. (2018) introduce health expenditures as a health indicator. They find a long-run unidirectional causality from REC\% to health care expenditures.
Focusing of 32 Sub-Saharan Africa countries, Baye et al. (2021) assess, among other variables, the impact of the quality of governance. They find a positive association between TREC and the improvement in the quality of governance. In his study of Tunisia, Ben Jebli (2016) obtains a bi-directional relationship between health and the consumption of combustible renewables. Ergun et al. (2019) examine the impact of the Human Development Index (HDI) and of the level of democracy, proxied by the aggregated weights of political rights and civil liberties ratings, on REC\% in Africa. They obtain a negative impact of the HDI on REC\%, while the effect of the level of democracy is non-significant. Khribich et al. (2021) construct a social development index using 17 variables on demography, education, health, consumption and IT and research for 27 high-income countries over the period 1995-2015, finding that social development contributes to REC\% in the long run but not in the short run. Finally, Marra and Colantonio (2021) examine the impact on REC\% in 12 EU countries of several socio-technical aspects, including educational attainment. They conclude that the combination of public awareness and environmental education can help RE deployment.

As was pointed out before, most of analyses employ the total value of renewable energy consumption as dependent variable. We find analyses for individual countries like China (Lin and Moubarak 2014; Chen 2018; Zhao et al. 2020), India (Eren et al. 2019), Tunisia (Ben Jebli 2016; Cherni and Jouini 2017) or the USA (Sohail et al. 2021), as well as studies for groups of countries, like the OECD countries (Apergis and Payne 2010a; Salim and Shafiei 2014; Salim et al. 2014), EU members from CEE (Marinaş et al. 2018), CIS region countries (Rasoulinezhad and Saboori 2018), African countries (Ben Aïssa et al. 2014; Olanrewaju et al. 2019; Baye et al. 2021), developed countries (Saidi and Ben Mbarek 2016) and both developed and developing countries (Apergis et al. 2010; Doytch and Narayan 2016; Nguyen and Kakinaka 2019). Other studies employ RECpc as a proxy of REC. We can cite the analysis of Tunisia conducted by Ben Jebli and Ben Youssef (2017) and studies for different groups of countries like the G7 countries (Sadorsky 2009a), some emerging countries (Sadorsky 2009b; Salim and Rafiq 2012; Hashemizadeh et al. 2021), Central American countries (Apergis and Payne 2014), African countries (Ben Jebli et al. 2015) or 64 high, low and middle-income countries (Omri et al. 2015). As was pointed out before, the number of studies that examine REC in relative terms, that is, as a share of total energy consumption (REC\%) is scarcer. Thus, at the individual country level we find recent analyses conducted for Mexico (Mele 2019), Saudi Arabia (Toumi and Toumi 2019) or China (Lei et al. 2021). Other studies focus on African countries (Apergis et al. 2018; Ergun et al. 2019), on developing countries (Ito 2017) on high-income countries (Khribich et al. 2021) and on European countries (Anton 
and Afloarei Nucu 2020; Marra and Colantonio 2021). As far as our knowledge, the widest study in terms of number of countries covered (192) was carried out by Khan et al. (2020). In this paper we widen the studies for the European countries conducted by Anton and Afloarei Nucu (2020) and Marra and Colantonio (2021) by comparing the results of the EU with those obtained at the world level and by including social factors. In the next section we describe the data and the methodology employed.

\section{Data and methodology}

\section{Data}

A total of 176 countries over the period 2001-2015 were examined. As mentioned before, we compare the results for the EU countries with those obtained for the whole panel of countries. Within the EU, we include the 28 countries that formed the EU in 2015, namely, Austria, Belgium, Bulgaria, Croatia, Republic of Cyprus, Czech Republic, Denmark, Estonia, Finland, France, Germany, Greece, Hungary, Ireland, Italy, Latvia, Lithuania, Luxembourg, Malta, Netherlands, Poland, Portugal, Romania, Slovakia, Slovenia, Spain Sweden and the UK. The list of countries examined is presented in Appendix Table 9.

The dependent variable (REC\%) is defined as the share of REC in total energy consumption. It was obtained from the World Development Indicators Database (World Bank 2019a).

We included three economic explanatory factors: gross domestic product per capita (GDPpc), foreign direct invesstment (FDI) and trade openness (TO) and three social explanatory factors: an education index (EI), a life expectancy index (LEI) and a governance index (GI). GDPpc captures economic growth and income distribution, and it is obtained by dividing the gross domestic product by population. In order to proxy economic growth in real terms, it is valued at constant prices of 2010 (World Bank 2019a). The second economic explanatory variable, FDI, is defined as the net investment inputs to acquire a lasting management interest (10\% or more of the voting stock) in a company operating in an economy other than that of the investor. It is the sum of equity capital, reinvestment of earnings, other long-term capital and short-term capital as shown in the balance of payments (World Bank 2019a). Finally, the third economic explanatory factor is TO. Although there are different forms of measuring TO (Yanikkaya 2003), in this study we adopt the definition of the World Bank, and we define it as the share of trade (sum of imports and exports of goods and services) in GDP (World Bank 2019a).

In addition to the economic variables, this study takes into consideration three social variables. The HDI developed by the United Nations Development Program (UNDP) measures three aspects: access to knowledge, a long and healthy life and a decent standard of living. The latter aspect is proxied by GDPpc. Our first two social explanatory factors are the two first components of the HDI, namely, the EI and LEI. The third social explanatory factor is a governance index (GI). The GI is a multidimensional index proposed by Kaufmann et al. (2010) and published by the World Bank (World Bank 2019b). The GI has been used in previous studies on other issues like the relationship between governance quality and net migration flows (Ariu et al. 2016), the link between governance and economic growth (Emara and Chiu 2016), the impact of terrorism on governance (Asongu and Nwachukwu 2017) or the effect of the use of mobile telephony in promoting good governance (Asongu et al. 2018). In our case the GI is constructed by combining the six following indicators:

- Voice and accountability: they measure the extent to which the citizens of a country can participate in the selection of their government, as well as freedom of expression, freedom of association and a free means.

- Political stability and absence of violence: it measures the likelihood of the government to be destabilized by unconstitutional or violent means, including terrorism.

- Government effectiveness: it measures the quality of public services, the capacity of the public administration and its independence from political pressures as well as the quality of policy-making.

- Regulatory quality: it measures the government's ability to provide sound policies and regulations that enable and promote private sector development.

- Rule of law: it measures the extent to which agents trust and respect the rules of society, including the quality of performance of contracts and property rights, the police and courts, as well as the likelihood of crime and violence.

- Control of corruption: it measures the extent to which public power is exercised to make private gains, including all forms of corruption, both small and large, as well as the "capture" of the state by elites and private interests.

To combine the six indicators, we conducted a Principal Component Analysis (PCA). This technique allows to reduce a set of correlated variables in a smaller group of uncorrelated variables, which are called components (Hair et al. 1999). The components are independent of each other and are a linear combination of the original variables. One of the main advantages of PCA is that it solves the problem of implicit weighting. The components represent in a decreasing and successive way the percentage of the variance explained from the original set of variables, where the 
first component represents the highest percentage of variation in the original set of variables, the second captures the largest percentage of the variation that is not explained by the previous one and so on. The results obtained in the Kaiser-Meyer-Olkin test was 0.886 , thus allowing to continue with the factorial analysis (Cureton and D'Agostino 2013). The value of the Cronbach's Alpha for our GI was 0.917, which confirms the adequacy of the index (Vaske et al. 2017).

\section{Methodology}

Following the literature review conducted in the second section, we specify a model based on economic variables and on social variables. From an economic point of view, there is a wide consensus in literature on the fact that economic growth, foreign investment and trade openness influence REC\%. However, social factors can make an important difference, especially in those countries with a high level of development. Thus, factors like the levels of education or governance are found to significantly influence REC\% (Baye et al. 2021; Marra and Colantonio 2021).

The model estimated can be summarized as follows:

$$
\begin{aligned}
\mathrm{REC}_{\mathrm{it}} & =\beta_{0}+\beta_{1} \mathrm{InGDPpc}_{\mathrm{it}}+\beta_{2} \mathrm{InFDI}_{\mathrm{it}} \\
& +\beta_{3} \mathrm{TO}_{\mathrm{it}}+\beta_{4} \mathrm{EI}_{\mathrm{it}}+\beta_{5} \mathrm{LEI}_{\mathrm{it}}+\beta_{6} \mathrm{GI}_{\mathrm{it}}+\mathrm{e}_{\mathrm{it}}
\end{aligned}
$$

where, $i$ denotes the country and $t$ the year; $\beta_{0}$ is the intercept, $\beta_{1}, \beta_{2}, \beta_{3}, \beta_{4}, \beta_{5}$, and $\beta_{6}$ are the long-run elasticities of dependent variable; $e$ denotes the error terms. REC\% is the variable related to share of REC, GDPpc is the gross domestic product per capita, FDI is the foreign direct investment, TO is the trade openness, EI is the education index, LEI is the life expectancy index and GI is the governance index.

Three types of econometric techniques are employed: Ordinary Least Squares (OLS), Feasible Generalized Least Square (FGLS) and Panel Corrected Standard Error (PCSE). According to Gujarati and Porter (2010), when information from the same cross-sectional units exists over time it is possible to design models where the combination of both types of data is used, which can be estimated through panel data techniques. Wooldridge (2010) points out that one of the main advantages of using panel data is that they allow to classify the nonobservable factors that influence the dependent variable into two types: those that are constant and those that vary over time (Arellano and Bover 1990; Wooldridge 2002; Plümper et al. 2005). Thus, panel data models can be estimated by using fixed effects or random effects. The fixed effects model considers that differences between units can be captured by differences in the intercept, which in turn implies that each intercept should be estimated. In contrast, the random effects model assumes that each cross-sectional unit has a different intercept. To choose between fixed effects and random effects the Hausman test is commonly employed (Hausman 1978). In spite of its advantages, panel data often present problems of serial autocorrelation, heteroscedasticity and even contemporary correlation (Canarella and Gasparyan 2008). According to Jönsson (2005) these problems arise when disturbances are dependent on the cross section, and these problems can be solved by applying a FGLS model (Parks 1967). However, as Beck and Katz (1995), highlight, the FGLS model produces coefficients whose standard errors are underestimated. In contrast, the PCSE model corrects the presence of serial autocorrelation, heteroscedasticity and even contemporary correlation, with accurate standard error estimates and little or no loss of efficiency compared to FGLS. To assess the independence between errors and the existence of a distribution with constant variance, the Wooldridge test (Wooldridge 2002) and the modified Wald test (Greene 2012) are conducted.

\section{Results and discussions}

Before entering into the results of the model, in Table 2 we compare the share of REC in total energy consumption in the different regions of the world in the beginning and at the end of the period analyzed and in 2018. As the most recent data provided by the World Bank (World Bank 2021) refer to 2015 , in order to capture recent changes in REC\% we estimated this variable using the data published by the IEA (IEA 2020b).

As can be noted, REC\% substantially increased over the period 2001-2018 in the EU. Nonetheless, despite the fact that the EU has a technological development level

Table 2 Share of REC in total energy consumption by region, 20012015-2018

\begin{tabular}{lrrr}
\hline Region & 2001 & 2015 & $2018^{*}$ \\
\hline East Asia and Pacific & 21.6 & 13.9 & 22.0 \\
Europe and Central Asia & 7.6 & 13.1 & 23.8 \\
European Union & 8.9 & 17.6 & 19.6 \\
Latin America and Caribbean & 27.8 & 27.6 & 34.4 \\
Middle East and North Africa & 2.2 & 1.6 & 3.1 \\
North America & 6.4 & 10.2 & 23.1 \\
South Asia & 53.0 & 38.3 & 38.7 \\
Sub-Saharan Africa & 72.9 & 70.1 & 55.7 \\
World & 17.6 & 18.1 & 16.9 \\
\hline
\end{tabular}

Note: *Own estimation from IEA

Source: World Bank (2021) and (IEA, 2020b) 
high enough for a strong production and investment on REC (Nicolini and Tavoni 2017; Lilliestam et al. 2019), its share was below the world average in all years. In contrast, regions such as sub-Saharan Africa, South Asia or Latin America and the Caribbean, which report the highest values of REC\%, are made up of developing or underdeveloped countries whose production of RE is based on traditional technologies, such as large hydroelectric dams and traditional biomass combustion (Ergun et al. 2019; Baye et al. 2021). Developing and underdeveloped countries outweighed developed countries in REC. Thus, according to the last report of REN21 (REN21 2021), if we compare the evolution of REC over the period 2007-2017 in the group of 37 high-developed member countries of the Organization for Economic Cooperation and Development (OECD) and in the group of non-OECD countries, the growth was substantially higher in non-OECD than in OECD countries (68\% compared to $42 \%$ ). However, if we express REC as a share of TFEC, the growth was lower in non-OECD countries than in OECD countries (29\% compared to $44 \%$ ). It is also necessary to highlight that $\mathrm{RE}$ investment varies across regions and countries. Thus, in 2019 considering all financing of RE capacity (excluding hydropower larger than $50 \mathrm{MW}$ ) China was the largest investor (30\%), followed by the USA (20\%), Europe (19\%) and Asia-Oceania (16\% excluding China and India). In contrast, the smallest shares were reported by Africa and the Middle East (5\%), the Americas (4\% excluding Brazil and the USA), India (3\%) and Brazil (4\%) (REN21 2021). These differences can be explained by the stronger economic growth and the improvements in energy access experienced by non-OECD countries and confirm the results of those studies on the renewable energy environment Kuznets curve (RKC). For instance, in their analysis of RKC by income groups, Naqvi et al. (2020) find a U-shaped RKC for high-income countries while in low-income countries the RKC shows an inverted U-shape.

In Table 3, we present the descriptive statistics for the independent and the dependent variables of our model computed for the period 2001-2015 both at the world and at the EU level.

In the case of our dependent variable, REC\%, as was pointed out before, the average share of RE in total energy consumption at the world level almost double the average share of RE in total energy consumption at the EU level over the period analyzed. The stronger level of economic and social development of the EU is confirmed by the higher mean values of all dependent variables. Thus, both GDPpc, FDI and TO are substantially higher among the EU countries than the world average. Concerning social variables, the major difference is found in terms of education and the minor one in terms of life expectancy. Obviously, the EU is a more homogeneous area than the world so differences across countries are lower within the EU, as confirmed by
Table 3 Descriptive statistics

\begin{tabular}{llrrrr}
\hline & Variable & \multicolumn{1}{c}{ Mean } & Std. dev & \multicolumn{1}{l}{ Min } & \multicolumn{1}{c}{ Max } \\
\hline World & REC\% & 29.930 & 30.021 & 0.000 & 98.343 \\
& lnGDPpc & 8.574 & 1.529 & 5.267 & 12.136 \\
& lnFDI & 20.303 & 2.640 & 10.361 & 27.322 \\
& TO & 93.541 & 59.296 & 0.167 & 860.800 \\
& EI & 60.424 & 18.159 & 12.000 & 94.100 \\
& LEI & 75.772 & 14.101 & 30.200 & 98.200 \\
European Union & GI & 27.475 & 15.169 & 0.000 & 56.084 \\
& REC\% & 15.109 & 11.454 & 0.000 & 53.248 \\
& lnGDPpc & 10.141 & 0.687 & 8.340 & 11.626 \\
& lnFDI & 22.669 & 1.832 & 14.509 & 27.322 \\
& TO & 114.405 & 62.863 & 45.609 & 416.389 \\
& EI & 81.185 & 6.459 & 65.700 & 94.100 \\
& LEI & 89.120 & 4.767 & 77.100 & 96.900 \\
& GI & 45.378 & 6.760 & 28.335 & 56.084 \\
\hline
\end{tabular}

the lower values of standard deviations. The sole exception is found in the case of TO, where the standard deviation is higher at the EU level than at the world level.

Once examined the descriptive statistics, Table 4 presents the correlation matrix among the variables under study, distinguishing again between the world and the EU. The preliminary analysis of correlation coefficients reveals the existence of some differential features in the EU compared to the world average. Overall, the relationship between the economic variables and REC\% is negative and significant. We have to note that the correlation coefficient between REC\% and lnGDP is particularly lower in the EU. Regarding social variables, there are important differences between the world and the EU. Thus, whereas the sign of education is positive in the EU, the correlation coefficient between REC\% and the EI is negative at the world level. In the case of the governance index, in the EU the relationship between the GI and REC\% is weaker compared to the correlation coefficient at the world level.

As it is widely known, the analysis of correlation coefficients disregards a number of factors such as heteroscedasticity or autocorrelation. To go deeper into the effect of economic and social factors and into the differential features of the EU, we estimate the model depicted in Eq. (1) by using three different econometric techniques: OLS, FGLS and PCSE. The model is estimated both for the world and for the European Union.

As was noted in the methodology sub-section, to adequately estimate the models it is necessary to conduct some tests. The Hausman test (Hausman 1978) is employed to choose between the fixed effects and the random effects model. The null hypothesis is rejected so the fixed-effects models is preferable. Once selected the fixed effects model, two specification tests were conducted, the Wooldridge test 
Table 4 Correlation matrix

\begin{tabular}{|c|c|c|c|c|c|c|c|c|}
\hline & Variable & REC\% & $\operatorname{lnGDPpc}$ & $\operatorname{lnFDI}$ & TO & EI & LEI & GI \\
\hline \multirow[t]{7}{*}{ World } & $\mathrm{REC} \%$ & 1 & & & & & & \\
\hline & $\operatorname{lnGDPpc}$ & $-0.693 * * *$ & 1 & & & & & \\
\hline & $\operatorname{lnFDI}$ & $-0.312 * * *$ & $0.529 * * *$ & 1 & & & & \\
\hline & TO & $-0.309 * * *$ & $0.303 * * *$ & $0.091 * * *$ & 1 & & & \\
\hline & EI & $-0.637 * * *$ & $0.824 * * *$ & $0.531 * * *$ & $0.252 * * *$ & 1 & & \\
\hline & LEI & $-0.677 * * *$ & $0.794 * * *$ & $0.513 * * *$ & $0.242 * * *$ & $0.797 * * *$ & 1 & \\
\hline & GI & $-0.473 * * *$ & $0.809 * * *$ & $0.402 * * *$ & $0.302 * * *$ & $0.725 * * *$ & $0.695 * * *$ & 1 \\
\hline \multirow[t]{7}{*}{ European Union } & REC $\%$ & 1 & & & & & & \\
\hline & $\operatorname{lnGDPpc}$ & $-0.102 * *$ & 1 & & & & & \\
\hline & $\operatorname{lnFDI}$ & $-0.347 * * *$ & $0.495 * * *$ & 1 & & & & \\
\hline & TO & $-0.296 * * *$ & $0.187 * * *$ & -0.031 & 1 & & & \\
\hline & EI & $0.180 * * *$ & $0.380 * * *$ & $0.259 * * *$ & 0.003 & 1 & & \\
\hline & LEI & $-0.086^{*}$ & $0.813 * * *$ & $0.471 * * *$ & 0.005 & $0.234 * * *$ & 1 & \\
\hline & GI & -0.011 & $0.832 * * *$ & $0.394 * * *$ & $0.255^{* * *} *$ & $0.477 * * *$ & $0.558 * * *$ & 1 \\
\hline
\end{tabular}

$* * * p \leq 0.001 ; * * p \leq 0.005 ; * p \leq 0.01$

Table 5 Results of the specification tests

\begin{tabular}{lllll}
\hline & World & & \multicolumn{2}{l}{ European Union } \\
\hline Hausman test & Chi2 & Prob & Chi2 & Prob \\
& -43.44 & 0.000 & -0.20 & 0.000 \\
Wooldridge test & $F$ & Prob & $F$ & Prob \\
& 85.996 & 0.000 & 71.27 & 0.000 \\
Modified Wald test & Chi2 & Prob & Chi2 & Prob \\
& $640,000.00$ & 0.000 & 2550.00 & 0.000 \\
\hline
\end{tabular}

(Wooldridge 2002) and the modified Wald test (Greene 2012). The Woolridge test rejects the null hypothesis of no serial correlation and the modified Wald test rejects the null hypothesis of homoscedasticity. Table 5 summarizes the results of the Hausman test and of the two specification tests.

Given the presence of autocorrelation and heteroscedasticity, the FGLS is a suitable model, as it is robust in this case. The estimation results are summarized in Table 6 . Additionally, the robustness of the results is tested by
Table 6 Regression results with economic and social variables

\begin{tabular}{|c|c|c|c|c|c|c|}
\hline \multirow[t]{2}{*}{ Variable } & \multicolumn{3}{|l|}{ World } & \multicolumn{3}{|c|}{ European Union } \\
\hline & OLS & FGLS & PCSE & OLS & FGLS & PCSE \\
\hline $\operatorname{lnGDPpc}$ & $\begin{array}{l}-10.549^{*} \\
(0.626)\end{array}$ & $\begin{array}{l}-9.714^{*} \\
(0.453)\end{array}$ & $\begin{array}{l}-8.275^{*} \\
(0.717)\end{array}$ & $\begin{array}{l}-3.254 \\
(2.051)\end{array}$ & $\begin{array}{l}-5.299 * \\
(1.405)\end{array}$ & $\begin{array}{l}-5.942 * \\
(1.806)\end{array}$ \\
\hline $\operatorname{lnFDI}$ & $\begin{array}{l}1.035^{*} \\
(0.199)\end{array}$ & $\begin{array}{l}0.073 * * * \\
(0.042)\end{array}$ & $\begin{array}{l}0.176 * * \\
(0.082)\end{array}$ & $\begin{array}{l}-3.052 * \\
(0.324)\end{array}$ & $\begin{array}{l}-0.276^{*} \\
(0.100)\end{array}$ & $\begin{array}{l}-0.515^{*} \\
(0.155)\end{array}$ \\
\hline TO & $\begin{array}{l}-0.065^{*} \\
(0.007)\end{array}$ & $\begin{array}{l}-0.004 \\
(0.003)\end{array}$ & $\begin{array}{l}-0.021^{*} \\
(0.005)\end{array}$ & $\begin{array}{l}-0.063 * \\
(0.008)\end{array}$ & $\begin{array}{l}-0.005 \\
(0.006)\end{array}$ & $\begin{array}{l}-0.039 * \\
(0.007)\end{array}$ \\
\hline EI & $\begin{array}{l}-0.330 * \\
(0.044)\end{array}$ & $\begin{array}{l}0.012 \\
(0.030)\end{array}$ & $\begin{array}{l}-0.134 * \\
(0.048)\end{array}$ & $\begin{array}{l}0.285^{*} \\
(0.090)\end{array}$ & $\begin{array}{l}0.566^{*} \\
(0.063)\end{array}$ & $\begin{array}{l}0.507^{*} \\
(0.089)\end{array}$ \\
\hline LEI & $\begin{array}{l}-0.797 * \\
(0.052)\end{array}$ & $\begin{array}{l}-0.510^{*} \\
(0.048)\end{array}$ & $\begin{array}{l}-0.606 * \\
(0.064)\end{array}$ & $\begin{array}{l}0.134 \\
(0.199)\end{array}$ & $\begin{array}{l}0.363^{*} \\
(0.144)\end{array}$ & $\begin{array}{l}0.393 * * * \\
(0.212)\end{array}$ \\
\hline GI & $\begin{array}{l}0.658^{*} \\
(0.046)\end{array}$ & $\begin{array}{l}0.039 \\
(0.027)\end{array}$ & $\begin{array}{l}0.190 * \\
(0.044)\end{array}$ & $\begin{array}{l}0.539 * \\
(0.149)\end{array}$ & $\begin{array}{l}-0.133 \\
(0.095)\end{array}$ & $\begin{array}{l}0.345 * * \\
(0.139)\end{array}$ \\
\hline Intercept & $\begin{array}{l}170.356^{*} \\
(4.021)\end{array}$ & $\begin{array}{l}149.136 * \\
(2.769)\end{array}$ & $\begin{array}{l}152.024 * \\
(4.040)\end{array}$ & $\begin{array}{l}65.135^{*} \\
(12.076)\end{array}$ & $\begin{array}{l}1.045 \\
(7.882)\end{array}$ & $\begin{array}{c}-0.478 \\
(12.256)\end{array}$ \\
\hline$N$ & 2277 & 2277 & 2277 & 364 & 364 & 364 \\
\hline Groups & & 176 & 176 & & 28 & 28 \\
\hline Wald $\mathrm{Chi}^{2}$ & & 2857.99 & 1447.97 & & 141.57 & 93.09 \\
\hline $\mathrm{Chi}^{2}$ prob & & 0.000 & 0.000 & & 0.000 & 0.000 \\
\hline$R^{2}$ & 0.594 & & 0.599 & 0.318 & & 0.360 \\
\hline
\end{tabular}


estimating the models including only the group of economic variables (Table 7) and only the group of social variables (Table 8).

Focusing on the coefficients of the PCSE model, we find that $\operatorname{lnGDPpc}$ and TO have negative and statistically significant effects on REC\% both at the world and at the EU level. In contrast, GI has a positive and statistically significant effect on REC\% both at the world and the EU level. The relationship between education and REC\% has different signs at the world and at the EU level. Thus, while the impact of the EI is positive and significant in the EU, it is negative and significant at the world level. The same happens in the case of life expectancy. In contrast, the signs are just the opposite in the case of FDI: the effect is positive and significant at the world level but negative and significant at the EU level. These differences in the sign of some of the variables between the EU and the world can be explained, at least partially, by the high level of development of the EU countries. If we compare the results with those obtained by including only economic variables (Table 7), the effects are the same with the sole exception of the coefficient of LnGDPpc in the EU, that is non-significant. Turning to the coefficients of the model with only social variables (Table 8), the main difference is found in the impact of the GI, which becomes non-significant at the world level and changes its sign at the EU level. We have to note, however, that in the EU, the coefficient for GI in the model with only social variables is significant at the $10 \%$ level while in the complete model is significant at the $1 \%$ level.
Table 7 Regression results with economic variables

Table 8 Regression results with social variables

\begin{tabular}{|c|c|c|c|c|c|c|}
\hline \multirow[t]{2}{*}{ Variable } & \multicolumn{3}{|l|}{ World } & \multicolumn{3}{|c|}{ European Union } \\
\hline & OLS & FGLS & PCSE & OLS & FGLS & PCSE \\
\hline $\operatorname{lnGDPpc}$ & $\begin{array}{l}-13.810 * \\
(0.354)\end{array}$ & $\begin{array}{l}-11.840^{*} \\
(0.266)\end{array}$ & $\begin{array}{l}-12.480 * \\
(0.397)\end{array}$ & $\begin{array}{l}2.562 * \\
(0.870)\end{array}$ & $\begin{array}{l}-2.338^{*} \\
(0.754)\end{array}$ & $\begin{array}{l}1.258 \\
(1.002)\end{array}$ \\
\hline $\operatorname{lnFDI}$ & $\begin{array}{l}0.373 * * * \\
(0.196)\end{array}$ & $\begin{array}{l}0.052 \\
(0.032)\end{array}$ & $\begin{array}{l}0.126 * * * \\
(0.068)\end{array}$ & $\begin{array}{l}-2.678^{*} \\
(0.321)\end{array}$ & $\begin{array}{l}-0.145 \\
(0.097)\end{array}$ & $\begin{array}{l}-0.234^{*} \\
(-0.135)\end{array}$ \\
\hline TO & $\begin{array}{l}-0.060 * \\
(0.008)\end{array}$ & $\begin{array}{l}-0.002 \\
(0.002)\end{array}$ & $\begin{array}{l}-0.017 * \\
(0.005)\end{array}$ & $\begin{array}{l}-0.058 * \\
(0.008)\end{array}$ & $\begin{array}{l}-0.008 \\
(0.006)\end{array}$ & $\begin{array}{l}-0.047^{*} \\
(-0.008)\end{array}$ \\
\hline Intercept & $\begin{array}{l}147.270 * \\
(3.466)\end{array}$ & $\begin{array}{l}128.901 * \\
(2.497)\end{array}$ & $\begin{array}{l}138.782 * \\
(3.519)\end{array}$ & $\begin{array}{l}56.325^{*} \\
(8.042)\end{array}$ & $\begin{array}{l}40.108^{*} \\
(7.248)\end{array}$ & $\begin{array}{l}14.311 \\
(9.482)\end{array}$ \\
\hline$N$ & 2554 & 2554 & 2554 & 390 & 390 & 390 \\
\hline Groups & & 184 & 184 & & 28 & 28 \\
\hline Wald $\mathrm{Chi}^{2}$ & & 2057.62 & 1111.80 & & 20.30 & 37.98 \\
\hline $\mathrm{Chi}^{2}$ prob & & 0.000 & 0.000 & & 0.000 & 0.000 \\
\hline$R^{2}$ & 0.496 & & 0.539 & 0.223 & & 0.292 \\
\hline
\end{tabular}

$* * * p \leq 0.10 ; * * p \leq 0.05 ; * p \leq 0.01$; standard errors in parentheses

\begin{tabular}{|c|c|c|c|c|c|c|}
\hline \multirow[t]{2}{*}{ Variable } & \multicolumn{3}{|l|}{ World } & \multicolumn{3}{|c|}{ European Union } \\
\hline & OLS & FGLS & PCSE & OLS & FGLS & PCSE \\
\hline EI & $\begin{array}{l}-0.538^{*} \\
(0.042)\end{array}$ & $\begin{array}{l}-0.186^{*} \\
(0.029)\end{array}$ & $\begin{array}{l}-0.281^{*} \\
(0.043)\end{array}$ & $\begin{array}{l}0.377^{*} \\
(0.103)\end{array}$ & $\begin{array}{l}0.114 * * \\
(0.046)\end{array}$ & $\begin{array}{l}0.270^{*} \\
(0.074)\end{array}$ \\
\hline LEI & $\begin{array}{l}-1.071^{*} \\
(0.052)\end{array}$ & $\begin{array}{l}-0.930 * \\
(0.045)\end{array}$ & $\begin{array}{l}-0.920^{*} \\
(0.060)\end{array}$ & $\begin{array}{l}-0.306^{* *} \\
(0.145)\end{array}$ & $\begin{array}{l}1.011 * \\
(0.137)\end{array}$ & $\begin{array}{l}0.569 * \\
(0.174)\end{array}$ \\
\hline GI & $\begin{array}{l}0.240 * \\
(0.042)\end{array}$ & $\begin{array}{l}-0.113^{*} \\
(0.025)\end{array}$ & $\begin{array}{l}-0.029 \\
(0.038)\end{array}$ & $\begin{array}{l}-0.029 \\
(0.113)\end{array}$ & $\begin{array}{l}-0.100^{* * *} \\
(0.053)\end{array}$ & $\begin{array}{l}-0.229^{*} \\
(0.080)\end{array}$ \\
\hline Intercept & $\begin{array}{l}140.806^{*} \\
(2.663)\end{array}$ & $\begin{array}{l}115.158^{*} \\
(2.561)\end{array}$ & $\begin{array}{l}120.987 * \\
(3.313)\end{array}$ & $\begin{array}{l}13.258 \\
(13.218)\end{array}$ & $\begin{array}{l}-84.782^{*} \\
(11.334)\end{array}$ & $\begin{array}{l}-46.468^{*} \\
(14.318)\end{array}$ \\
\hline$N$ & 2542 & 2542 & 2542 & 392 & 392 & 392 \\
\hline Groups & & 186 & 186 & & 28 & 28 \\
\hline Wald $\mathrm{Chi}^{2}$ & & 1736.25 & 1002.92 & & 103.30 & 48.92 \\
\hline $\mathrm{Chi}^{2}$ prob & & 0.000 & 0.000 & & 0.000 & 0.000 \\
\hline$R^{2}$ & 0.487 & & 0.509 & 0.047 & & 0.360 \\
\hline
\end{tabular}

$* * * p \leq 0.10, * * p \leq 0.05, * p \leq 0.01$; standard errors in parentheses 
If we compare the results obtained for the EU with those of previous studies on REC in the European countries, we find similarities when the same dependent variable is examined. Thus, the results of the studies by Anton and Afloarei Nucu (2020) and by Marra and Colantonio (2021) that use REC\% as dependent variable also show the existence of a negative impact of the level of economic development on $\mathrm{REC} \%$ in the EU countries. Among other reasons, they argue that a high economic growth results into a higher energy demand that cannot be immediately satisfied by renewable sources. In this sense, the study of Marinaş et al. (2018) that analyzed the impact of GDP on TREC in 10 EU countries from Central and Eastern European countries found that GDP growth has a positive long-term effect on TREC. Regarding FDI, as in our case, Anton and Afloarei Nucu (2020) obtain a negative impact of FDI on REC\%. They explain this negative relationship by the fact that FDI fosters investment and innovations by firms, and these cause a reduction in energy use. As was noted before, the coefficient obtained for FDI at the world level is positive. Previous literature on the impact of FDI on REC also obtained mixed results. For instance, the analysis of Doytch and Narayan (2016) find different effects depending on the sector, and the study of Khan et al. (2020) shows the existence of different impacts among countries. As Pacesila et al. (2016) and Gökgöz and Güvercin (2018) highlight, this can be explained by differences in a wide range of factors from the size of the country to its energy policy or energy security.

Entering into the impact of social variables, as was pointed in the review of the literature, the studies incorporating this type of variables are quite scarce. If we focus on the study by Ergun et al. (2019) for African countries that incorporates the HDI and a democracy indicator as explanatory variables of REC\%, we can also find some similarities with respect to our results. As Ergun et al. (2019) point out, a higher HDI implies not only a higher income level but also a higher life expectancy and education level. However, they find that a higher HDI reduces REC\% in Africa. In our case both life expectancy and education exert a positive impact on REC\% in the EU, but the impact is negative at the world level. This differential behavior can be explained by the differences in the development level of EU countries and African countries and more concretely by the "traditional" character of RE production and consumption in the latter ones. For instance, electrification rates are low in African countries, and most of RE used for cooking comes from burning wood. Regarding the level of democracy, Ergun et al. (2019) do not find any statistically significant impact. In their examination of 27 high-income countries, including most of EU countries, Khribich et al. (2021) conclude that social development positively affects REC in the long run. Their definition of social development covers five main aspects: demographic, education, health, consumption and
IT and research. Their simulations show that it is necessary an increase in the growth of social development in order to achieve a positive impact of social development in the short run. Finally, in line with our findings, the analysis of 32 Sub-Saharan Africa countries carried out by Baye et al. (2021) finds that the quality of governance has a positive impact on REC\%. The effect of education on REC\% is also positive in the study of $12 \mathrm{EU}$ countries conducted by Marra and Colantonio (2021). They conclude that a mix between education and public awareness about environmental issues is key to renewable energy deployment.

\section{Conclusions}

This study analyzed how economic and social factors affected the share of REC in the EU over the period 2001-2015. The results obtained confirmed that, in order to adequately identify which are the main driving factors of REC, regions and countries have to be examined by taking into consideration their particularities, as the same factor may have different impacts depending on the country or region examined.

This study contributed to the extant literature on REC in two main ways. First, it incorporates not only economic but also social factors to the analysis. A large body of the literature on the driving forces of REC includes economic variables. However, there is a lack of evidence on the impact of social factors, especially in high-income countries. We examine the impact of three social factors: education, life expectancy and governance. Second, it compares the results for the EU with those obtained at the world level to identify differential features.

Concerning the two types of factors distinguished, we found that economic factors have a negative effect on REC while social factors have a positive impact in the EU. This means that to facilitate energy transition the EU is called to affect social aspects. In particular, efforts to improve the institutional framework and governance should be conducted. Additionally, the EU should carry out programs to raise awareness of the importance of the use of clean and renewable energy and to promote energy efficiency.

We found that the impact of some factors was different at the EU level and at the world level. Thus, education and life expectancy exert a positive effect on RE consumption in the EU while the impact is negative at the world level. This can be explained, at least in part, by the high level of development of the EU countries compared to the world average. Given the differences in the impact of some the factors examined, national governments should adapt their energy policy to the specific features of their countries. For instance, in the case of developed and developing countries efforts should focus 
on reducing energy poverty and attracting foreign investments in RE infrastructures.

To conclude, we can affirm that the deployment of RE is influenced by a wide range of factors. In this paper we found that social aspects play a key role in the uptake of RE consumption in the EU. Therefore, it is necessary to adopt a holistic approach that includes not only economic but also social aspects in order to foster the consumption of RE. In this sense, EU governments could implement programs in the different levels of the education systems (schools and universities) aimed at developing knowledge, skills and attitudes to raise environmental awareness and encourage changes in energy use.

\section{Appendix}

Table 9

Table 9 Country list of empirical econometric models

\begin{tabular}{|c|c|c|c|c|c|}
\hline Afghanistan & Canada & Georgia & Lao PDR & Nigeria & St. Lucia \\
\hline Albania & Central African Republic & Germany & Latvia & Norway & $\begin{array}{l}\text { Vincent and the Gren- } \\
\text { adines }\end{array}$ \\
\hline Algeria & Chad & Ghana & Lebanon & Oman & Sudan \\
\hline Angola & Chile & Greece & Lesotho & Pakistan & Sweden \\
\hline Antigua and Barbuda & China & Grenada & Liberia & Palau & Switzerland \\
\hline Argentina & Colombia & Guatemala & Libya & Panama & Tajikistan \\
\hline Armenia & Comoros & Guinea & Lithuania & Papua New Guinea & Tanzania \\
\hline Australia & Congo, Dem. Rep & Guinea-Bissau & Luxembourg & Paraguay & Thailand \\
\hline Austria & Congo, Rep & Guyana & Madagascar & Peru & Timor-Leste \\
\hline Azerbaijan & Costa Rica & Haiti & Malawi & Philippines & Togo \\
\hline Bahamas, The & Cote d'Ivoire & Honduras & Malaysia & Poland & Tonga \\
\hline Bahrain & Croatia & $\begin{array}{l}\text { Hong Kong SAR, } \\
\text { China }\end{array}$ & Maldives & Portugal & Tunisia \\
\hline Bangladesh & Cyprus & Hungary & Mali & Qatar & Turkey \\
\hline Barbados & Czech Republic & Iceland & Malta & Romania & Turkmenistan \\
\hline Belarus & Denmark & India & Mauritania & Russian Federation & Uganda \\
\hline Belgium & Dominica & Indonesia & Mauritius & Rwanda & Ukraine \\
\hline Belize & Dominican Republic & Iran, Islamic Rep & Mexico & Samoa & United Arab Emirates \\
\hline Benin & Ecuador & Iraq & Micronesia, Fed. Sts & Saudi Arabia & United Kingdom \\
\hline Bhutan & Egypt, Arab Rep & Ireland & Moldova & Senegal & USA \\
\hline Bolivia & El Salvador & Israel & Mongolia & Serbia & Uruguay \\
\hline $\begin{array}{l}\text { Bosnia and Herzego- } \\
\text { vina }\end{array}$ & Equatorial Guinea & Italy & Montenegro & Seychelles & Uzbekistan \\
\hline Botswana & Eritrea & Jamaica & Morocco & Sierra Leone & Vanuatu \\
\hline Brazil & Estonia & Japan & Mozambique & Singapore & Venezuela, RB \\
\hline Brunei Darussalam & Eswatini & Jordan & Myanmar & Slovak Republic & Vietnam \\
\hline Bulgaria & Ethiopia & Kazakhstan & Namibia & Slovenia & Zambia \\
\hline Burkina Faso & Fiji & Kenya & Nepal & Solomon Islands & Zimbabwe \\
\hline Burundi & Finland & Kiribati & Netherlands & South Africa & \\
\hline Cabo Verde & France & Korea, Rep & New Zealand & Spain & \\
\hline Cambodia & Gabon & Kuwait & Nicaragua & Sri Lanka & \\
\hline Cameroon & Gambia, The & Kyrgyz Republic & Niger & St. Kitts and Nevis & \\
\hline
\end{tabular}


Acknowledgements We thank the project "Adaptation to sustainable energy transition in Europe: Environmental, socio-economic and cultural aspects (ADAPTAS)" (Ministry of Economy, Industry, and Competitiveness and State Research Agency of Spain, and European Regional Development Fund, No. CSO2017- 86975-R). And the University of Granada / CBUA for funding for the open access charge.

Author contribution All authors contributed to the study conception and design. Material preparation, data collection and analysis were performed by JACB, LDSA and MR. The first draft of the manuscript was written by LDSA, and all authors commented on previous versions of the manuscript. All authors read and approved the final manuscript.

Funding Funding for open access charge: Universidad de Granada / CBUA. The Ministry of Economy, Industry, and Competitiveness and State Research Agency of Spain, and European Regional Development Fund, No. CS02017-86975-R, which finances the project "Adaptation to sustainable energy transition in Europe: Environmental, socio-economic and cultural aspects (ADAPTAS)" that financed the obtaining of the data for elaboration of this paper.

Data availability All data generated or analyzed during this study has its sources of public access informed or is included in this published article.

\section{Declarations}

Ethics approval and consent to participate Not applicable.

Consent for publication Not applicable.

Conflict of interest The authors declare no competing interests.

Open Access This article is licensed under a Creative Commons Attribution 4.0 International License, which permits use, sharing, adaptation, distribution and reproduction in any medium or format, as long as you give appropriate credit to the original author(s) and the source, provide a link to the Creative Commons licence, and indicate if changes were made. The images or other third party material in this article are included in the article's Creative Commons licence, unless indicated otherwise in a credit line to the material. If material is not included in the article's Creative Commons licence and your intended use is not permitted by statutory regulation or exceeds the permitted use, you will need to obtain permission directly from the copyright holder. To view a copy of this licence, visit http://creativecommons. org/licenses/by/4.0/.

\section{References}

Al-Mulali U, Fereidouni HG, Lee JY, Sab CNBC (2013) Examining the bi-directional long run relationship between renewable energy consumption and GDP growth. Renew Sust Energ Rev 22:209222. https://doi.org/10.1016/j.rser.2013.02.005

Amri F (2017) Intercourse across economic growth, trade and renewable energy consumption in developing and developed countries. Renew Sust Energ Rev 69:527-534. https://doi.org/10.1016/J. RSER.2016.11.230

Amri F (2019) Renewable and non-renewable categories of energy consumption and trade: do the development degree and the industrialization degree matter? Energy 173:374-383. https://doi.org/ 10.1016/j.energy.2019.02.114
Anton SG, AfloareiNucu AE (2020) The effect of financial development on renewable energy consumption. A panel data approach Renew Energy 147:330-338. https://doi.org/10.1016/j.renene. 2019.09.005

Apergis N, Payne JE (2010) Renewable energy consumption and economic growth: evidence from a panel of OECD countries. Energy Policy 38:656-660. https://doi.org/10.1016/j.enpol.2009.09.002

Apergis N, Payne JE (2010) Renewable energy consumption and growth in Eurasia. Energy Econ 32:1392-1397. https://doi.org/ 10.1016/j.eneco.2010.06.001

Apergis N, Payne JE, Menyah K, Wolde-Rufael Y (2010) On the causal dynamics between emissions, nuclear energy, renewable energy, and economic growth. Ecol Econ 69:2255-2260. https://doi.org/ 10.1016/j.ecolecon.2010.06.014

Apergis N, Payne JE (2011) On the causal dynamics between renewable and non-renewable energy consumption and economic growth in developed and developing countries. Energy Syst 2:299-312. https://doi.org/10.1007/s12667-011-0037-6

Apergis N, Payne JE (2012) Renewable and non-renewable energy consumption-growth nexus: evidence from a panel error correction model. Energy Econ 34:733-738. https://doi.org/10.1016/j. eneco.2011.04.007

Apergis N, Payne JE (2014) Renewable energy, output, CO2 emissions, and fossil fuel prices in Central America: evidence from a nonlinear panel smooth transition vector error correction model. Energy Econ 42:226-232. https://doi.org/10.1016/j.eneco.2014.01.003

Apergis N, Ben Jebli M, Ben Youssef S (2018) Does renewable energy consumption and health expenditures decrease carbon dioxide emissions? Evidence for sub-Saharan Africa countries. Renew Energy 127:1011-1016. https://doi.org/10.1016/j.renene.2018. 05.043

Arellano M, Bover O (1990) La econometria de datos de panel. Investig Económicas (Segunda época) XIV:3-45

Ariu A, Docquier F, Squicciarini MP (2016) Governance quality and net migration flows. Reg Sci Urban Econ 60:238-248. https://doi. org/10.1016/J.REGSCIURBECO.2016.07.006

Asongu S, Le Roux S, Nwachukwu JC, Pyke C (2018) The mobile phone as an argument for good governance in sub-Saharan Africa. Inf Technol People 32:364-386. https://doi.org/10.1108/ ITP-01-2018-0011

Asongu SA, Nwachukwu JC (2017) The impact of terrorism on governance in African Countries. World Dev 99:253-270. https://doi.org/ 10.1016/J.WORLDDEV.2017.05.023

Attiaoui I, Toumi H, Ammouri B, Gargouri I (2017) Causality links among renewable energy consumption, CO 2 emissions, and economic growth in Africa: evidence from a panel ARDL-PMG approach. Environ Sci Pollut Res 24:13036-13048. https://doi. org/10.1007/s11356-017-8850-7

Banja M, Jégard M, Monforti-Ferrario F, et al (2018) Renewables in the EU an overview of support schemes and measures. Brussels

Baye RS, Olper A, Ahenkan A et al (2021) Renewable energy consumption in Africa: evidence from a bias corrected dynamic panel. Sci Total Environ 766:142583. https://doi.org/10.1016/J. SCITOTENV.2020.142583

Beck N, Katz JN (1995) What to do (and not to do) with time-series cross-section data. Am Polit Sci Rev 89:634-647. https://doi.org/ $10.2307 / 2082979$

Ben Aïssa MS, Ben Jebli M, Ben Youssef S (2014) Output, renewable energy consumption and trade in Africa. Energy Policy 66:11-18. https://doi.org/10.1016/J.ENPOL.2013.11.023

Ben Jebli M (2016) On the causal links between health indicator, output, combustible renewables and waste consumption, rail transport, and CO2emissions: the case of Tunisia. Environ Sci Pollut Res 23:16699-16715. https://doi.org/10.1007/s11356-016-6850-7

Ben Jebli M, Ben Youssef S (2017) Renewable energy consumption and agriculture: evidence for cointegration and Granger causality 
for Tunisian economy. Int J Sustain Dev World Ecol 24:149-158. https://doi.org/10.1080/13504509.2016.1196467

Ben Jebli M, Ben Youssef S, Ozturk I (2015) The role of renewable energy consumption and trade: environmental Kuznets curve analysis for sub-Saharan Africa countries. African Dev Rev 27:288-300. https://doi.org/10.1111/1467-8268.12147

Canarella G, Gasparyan A (2008) New insights into executive compensation and firm performance: evidence from a panel of "new economy" firms, 1996-2002. Manag Financ 34:537-554. https:// doi.org/10.1108/03074350810874064

Chen Y (2018) Factors influencing renewable energy consumption in China: an empirical analysis based on provincial panel data. J Clean Prod 174:605-615. https://doi.org/10.1016/j.jclepro.2017. 11.011

Cherni A, Jouini SE (2017) An ARDL approach to the CO2 emissions, renewable energy and economic growth nexus: Tunisian evidence. Int J Hydrogen Energy 42:29056-29066. https://doi.org/10.1016/j. ijhydene.2017.08.072

Cureton EE, D’Agostino RB (2013) Factor analysis: an aplied approach, 1 st edn. Psychology Press, New York

Doytch N, Narayan S (2016) Does FDI influence renewable energy consumption? An analysis of sectoral FDI impact on renewable and non-renewable industrial energy consumption. Energy Econ 54:291-301. https://doi.org/10.1016/j.eneco.2015.12.010

Emara N, Chiu I-M (2016) The impact of governance on economic growth: the case of Middle Eastern and North African countries. Top Middle East African Econ 18:126-144

Eren BM, Taspinar N, Gokmenoglu KK (2019) The impact of financial development and economic growth on renewable energy consumption: empirical analysis of India. Sci Total Environ 663:189197. https://doi.org/10.1016/j.scitotenv.2019.01.323

Ergun SJ, Owusu PA, Rivas MF (2019) Determinants of renewable energy consumption in Africa. Environ Sci Pollut Res 26:15390 15405. https://doi.org/10.1007/s11356-019-04567-7

European Parliament (2019) La energía renovable I Fichas temáticas sobre la Unión Europea I Parlamento Europeo. http://www. europarl.europa.eu/factsheets/es/sheet/70/la-energia-renovable. Accessed 26 Sep 2019

European Union (2018) Directive (EU) 2018/2001 of the European parliament and of the council—of 11 December 2018—on the promotion of the use of energy from renewable sources (recast). In: Off. J. Eur. Union. https://eur-lex.europa.eu/legal-content/EN/ TXT/PDF/?uri=CELEX:32018L2001\&from $=$ EN. Accessed 6 Jun 2019

Eurostat (2021) Renewable energy statistics—statistics explained. In: Eur. Comm. https://ec.europa.eu/eurostat/statistics-explained/ index.php/Renewable_energy_statistics\#Share_of_renewable_ energy_more_than_doubled_between_2004_and_2019. Accessed 23 Apr 2021

Gökgöz F, Güvercin MT (2018) Energy security and renewable energy efficiency in EU. Renew Sust Energ Rev 96:226-239. https://doi. org/10.1016/j.rser.2018.07.046

Greene WH (2012) Econometric analysis, 7th edn. Prentice Hall, New York

Gujarati DN, Porter DC (2010) Econometría, 5a . McGraw-Hill, Ciudad de México

Hair JF, Anderson RE, Tatham RL, Black WC (1999) Análisis Multivariante, vol 491. Prentice Hall, Madrid

Hashemizadeh A, Bui Q, Kongbuamai N (2021) Unpacking the role of public debt in renewable energy consumption: new insights from the emerging countries. Energy 224:120187. https://doi.org/10. 1016/j.energy.2021.120187

Hausman JA (1978) Specification tests in econometrics. Econometrica 46:1251-1271. https://doi.org/10.2307/1913827
IEA (2020a) World Energy Balances Highlights (2020 edition). In: Data Stat. Int. Energy Agency. https://www.iea.org/subscribe-todata-services/world-energy-balances-and-statistics. Accessed 4 Feb 2021

IEA (2020b) Data \& statistics-International Energy Agency. https:// www.iea.org/data-and-statistics. Accessed 11 Feb 2020

Ito K (2017) CO2 emissions, renewable and non-renewable energy consumption, and economic growth: evidence from panel data for developing countries. Int Econ 151:1-6. https://doi.org/10.1016/j. inteco.2017.02.001

Jönsson K (2005) Cross-sectional dependency and size distortion in a small-sample homogeneous panel data unit root test. Oxf Bull Econ Stat 67:369-392. https://doi.org/10.1111/j.1468-0084.2005. 00124.x

Kaufmann D, Kraay A, Mastruzzi M (2010) The worldwide governance indicators: methodology and analytical issues. In: World Bank Policy Res. Work. Pap. No. 5430. http://papers.ssrn.com/ sol3/papers.cfm?abstract_id=1682130. Accessed 10 Jun 2019

Khan H, Khan I, Binh TT (2020) The heterogeneity of renewable energy consumption, carbon emission and financial development in the globe: a panel quantile regression approach. Energy Rep 6:859-867. https://doi.org/10.1016/j.egyr.2020.04.002

Khribich A, Kacem RH, Dakhlaoui A (2021) Causality nexus of renewable energy consumption and social development: evidence from high-income countries. Renew Energy 169:14-22. https://doi.org/ 10.1016/J.RENENE.2021.01.005

Kraft J, Kraft A (1978) On the relationship between energy and GNP. J Energy Dev 3:401-403. https://doi.org/10.2307/24806805

Lei W, Liu L, Hafeez M, Sohail S (2021) Do economic policy uncertainty and financial development influence the renewable energy consumption levels in China? Environ Sci Pollut Res 1-10. https:// doi.org/10.1007/s11356-021-16194-2

Lilliestam J, Thonig R, Späth L, et al (2019) Policy pathways for the energy transition in Europe and selected European countries. Deliverable 7.2 (MUSTEC), Deliverable 1 (SCCER JA IDEA). Zürich

Lin B, Moubarak M (2014) Renewable energy consumption-economic growth nexus for China. Renew Sust Energ Rev 40:111117. https://doi.org/10.1016/j.rser.2014.07.128

Marinaş M-C, Dinu M, Socol A-G, Socol C (2018) Renewable energy consumption and economic growth. Causality relationship in Central and Eastern European countries. PLoS ONE 13:1-29. https:// doi.org/10.1371/journal.pone.0202951

Marra A, Colantonio E (2021) The path to renewable energy consumption in the European Union through drivers and barriers: a panel vector autoregressive approach. Socioecon Plann Sci 76:100958. https://doi.org/10.1016/j.seps.2020.100958

Mele M (2019) Renewable energy consumption: the effects on economic growth in Mexico. Int J Energy Econ Policy 9:269-273. https://doi.org/10.32479/ijeep.7460

Naqvi SAA, Shah SAR, Anwar S (2020) Raza H (2020) Renewable energy, economic development, and ecological footprint nexus: fresh evidence of renewable energy environment Kuznets curve (RKC) from income groups. Environ Sci Pollut Res 282(28):20312051. https://doi.org/10.1007/S11356-020-10485-W

Nguyen KH, Kakinaka M (2019) Renewable energy consumption, carbon emissions, and development stages: some evidence from panel cointegration analysis. Renew Energy 132:1049-1057. https://doi.org/10.1016/j.renene.2018.08.069

Nicolini M, Tavoni M (2017) Are renewable energy subsidies effective? Evidence from Europe. Renew Sust Energ Rev 74:412-423. https://doi.org/10.1016/j.rser.2016.12.032

Olanrewaju BT, Olubusoye OE, Adenikinju A, Akintande OJ (2019) A panel data analysis of renewable energy consumption in Africa. Renew Energy 140:668-679. https://doi.org/10.1016/j.renene. 2019.02.061 
Omri A, Daly S, Nguyen DK (2015) A robust analysis of the relationship between renewable energy consumption and its main drivers. Appl Econ 47:2913-2923. https://doi.org/10.1080/00036846. 2015.1011312

Owen AD (2006) Renewable energy: Externality costs as market barriers. Energy Policy 34:632-642. https://doi.org/10.1016/j.enpol. 2005.11.017

Pacesila M, Burcea SG, Colesca SE (2016) Analysis of renewable energies in European Union. Renew Sust Energ Rev 56:156-170. https://doi.org/10.1016/j.rser.2015.10.152

Painuly J (2001) Barriers to renewable energy penetration; a framework for analysis. Renew Energy 24:73-89. https://doi.org/10. 1016/S0960-1481(00)00186-5

Parks RW (1967) Efficient estimation of a system of regression equations when disturbances are both serially and contemporaneously correlated. J Am Stat Assoc 62:500-509. https://doi.org/10.1080/ 01621459.1967.10482923

Plümper T, Troeger VE, Manow P (2005) Panel data analysis in comparative politics: linking method to theory. Eur J Polit Res 44:327-354. https://doi.org/10.1111/j.1475-6765.2005.00230.x

Rasoulinezhad E, Saboori B (2018) Panel estimation for renewable and non-renewable energy consumption, economic growth, $\mathrm{CO} 2 \mathrm{emis}-$ sions, the composite trade intensity, and financial openness of the commonwealth of independent states. Environ Sci Pollut Res 25:17354-17370. https://doi.org/10.1007/s11356-018-1827-3

REN21 (2021) Renewables 2021 Global Status Report. Paris

Sadorsky P (2009) Renewable energy consumption, CO2 emissions and oil prices in the G7 countries. Energy Econ 31:456-462. https:// doi.org/10.1016/j.eneco.2008.12.010

Sadorsky P (2009) Renewable energy consumption and income in emerging economies. Energy Policy 37:4021-4028. https://doi. org/10.1016/j.enpol.2009.05.003

Saidi K, Ben Mbarek M (2016) Nuclear energy, renewable energy, $\mathrm{CO} 2$ emissions, and economic growth for nine developed countries: evidence from panel Granger causality tests. Prog Nucl Energy 88:364-374. https://doi.org/10.1016/j.pnucene.2016.01. 018

Saint Akadiri S, Alola AA, Akadiri AC, Alola UV (2019) Renewable energy consumption in EU-28 countries: policy toward pollution mitigation and economic sustainability. Energy Policy 132:803810. https://doi.org/10.1016/j.enpol.2019.06.040

Salim RA, Hassan K, Shafiei S (2014) Renewable and non-renewable energy consumption and economic activities: further evidence from OECD countries. Energy Econ 44:350-360. https://doi.org/ 10.1016/j.eneco.2014.05.001

Salim RA, Rafiq S (2012) Why do some emerging economies proactively accelerate the adoption of renewable energy? Energy Econ 34:1051-1057. https://doi.org/10.1016/J.ENECO.2011.08.015

Salim RA, Shafiei S (2014) Urbanization and renewable and nonrenewable energy consumption in OECD countries: an empirical analysis. Econ Model 38:581-591. https://doi.org/10.1016/j. econmod.2014.02.008
Sebri M, Ben-Salha O (2014) On the causal dynamics between economic growth, renewable energy consumption, $\mathrm{CO} 2 \mathrm{emissions}$ and trade openness: fresh evidence from BRICS countries. Renew Sust Energ Rev 39:14-23. https://doi.org/10.1016/j.rser.2014.07.033

Sen S, Ganguly S (2017) Opportunities, barriers and issues with renewable energy development-a discussion. Renew Sust Energ Rev 69:1170-1181. https://doi.org/10.1016/j.rser.2016.09.137

Sohail MT, Xiuyuan Y, Usman A, et al (2021) Renewable energy and non-renewable energy consumption: assessing the asymmetric role of monetary policy uncertainty in energy consumption. Environ Sci Pollut Res 1-10. https://doi.org/10.1007/ s11356-021-12867-0

Toumi S, Toumi H (2019) Asymmetric causality among renewable energy consumption, $\mathrm{CO} 2$ emissions, and economic growth in KSA: evidence from a non-linear ARDL model. Environ Sci Pollut Res 26:1-12. https://doi.org/10.1007/s11356-019-04955-z

Vaske JJ, Beaman J, Sponarski CC (2017) Rethinking internal consistency in Cronbach's alpha. Leis Sci 39:163-173. https://doi.org/ 10.1080/01490400.2015.1127189

Verbruggen A, Fischedick M, Moomaw W et al (2010) Renewable energy costs, potentials, barriers: conceptual issues. Energy Policy 38:850-861. https://doi.org/10.1016/j.enpol.2009.10.036

Wooldridge JM (2010) Introducción a la econometría: Un enfoque moderno, 4a. edición. Cegage Learning, Santa Fe

Wooldridge JM (2002) Econometric analysis of cross section and panel data, 1st edition. The MIT Press, Cambridge and London

World Bank (2019a) World Development Indicators I DataBank. https://databank.worldbank.org/source/world-development-indic ators. Accessed 19 Jun 2019

World Bank (2019b) Worldwide Governance Indicators I DataBank. https://databank.worldbank.org/reports.aspx ?source=worldwidegovernance-indicators. Accessed 25 Jun 2019

World Bank (2021) World Development Indicators, Sustainable Energy for All (SE4ALL) database from the SE4ALL Global Tracking Framework led jointly by the World Bank, International Energy Agency, and the Energy Sector Management Assistance Program. https://databank.worldbank.org/source/world-development-indic ators\#. Accessed 17 May 2021

Yanikkaya H (2003) Trade openness and economic growth: a crosscountry empirical investigation. J Dev Econ 72:57-89. https://doi. org/10.1016/S0304-3878(03)00068-3

Zhao P, Lu Z, Fang J et al (2020) Determinants of renewable and non-renewable energy demand in China. Struct Chang Econ Dyn 54:202-209. https://doi.org/10.1016/j.strueco.2020.05.002

Publisher's note Springer Nature remains neutral with regard to jurisdictional claims in published maps and institutional affiliations. 